\title{
Restructuring Science Teaching in Nigerian Tertiary Institutions
}

\author{
AbdulRahaman I. Ibrahim* \\ Jigawa State University, Kafin Hausa, Nigeria \\ *Corresponding author: abdulrahamanibrahim2@gmail.com
}

Received September 15, 2014; Revised November 12, 2014; Accepted November 24, 2014

\begin{abstract}
only few, if at all there is any, teachers who did not desire in their hearts to do what is best but the question is, why the poor students performance? One of the basic qualities of a curriculum is dynamism, therefore there is need to examine those activities that could promote Science teaching in Tertiary Institutions. Of course the general observation of current happenings in Nigerian tertiary institutions revealed that there is a decline in student enrolment in science courses, students are performing poorly academically and that science has not been taught as expected. For these reasons there is a need for science teachers to adopt practices which will encourage students to put more efforts in their study and analyze data as scientists do. Recommendations are made toward promoting science teaching and at the same time assist in increasing the number of trained and qualified science teachers in Nigerian schools.
\end{abstract}

Keywords: the general observation of current happenings in Nigerian tertiary

Cite This Article: AbdulRahaman I. Ibrahim, "Restructuring Science Teaching in Nigerian Tertiary Institutions." American Journal of Educational Research, vol. 2, no. 11 (2014): 1100-1103. doi: 10.12691/education-2-11-16.

\section{Introduction}

In education, not only must somebody (Teacher) be doing something but in return, something (Student Learning) must also be happening as directed through a prescribed curriculum. Across the nation the importance of Science in life is far reaching, not only because we live in an age where every technological discovery and innovation has something to do with Science but rather because Sciences promote understanding of the world we live in. In short if Science programme are properly handled and effectively implemented it is expected to give students things to think about and do and at the same time encourage acquisition of necessary skills.

Traditionally the style of teaching in the past follows a pattern such that a teacher sees himself/herself as a sole authority, therefore teaching is seen as telling and learning implies passive "listening”. According to Silva (1982), today's knowledge about man and his environment is dated back to the pre-historical time and a lot of the improvements made so far are through the process of inquiry and discovery rather than through trial and error. This suggests that if students are to learn science in tertiary institutions the way it ought to be, they need to be shown the way or view of scientists of the late 20th century.

In other words, for students to learn science effectively, they would have to be taught appropriately using the right methodology, selection of appropriate instructional materials and using the right evaluation techniques. More importantly there would be need for critical thinking through experimentation and the prescribed contents should allow the students to observe, classify, formulate, experiment and interprete the important steps or skills in scientific enquiry which the early scientists.

From experience there are indications suggesting that learning by listening can never be as effective as learning by "doing". Although the new science programme at all levels of education no longer see the students as subjects to be filled with facts, efforts are being made to help the learners develop an understanding and appreciation of the world through practical experiences.

Of course the importance of science in Nigerian educational system cannot be over emphasized. In fact Abdullahi (1982) argued that science teaching is essential and could be an instrument through which technology, economical and political break through can be achieved. To him, if sciences or technology has helped other western countries like United Kingdom, America, Japan and Germany to greatness then there is need to examine those factors that can assist in promoting enrollment of Students in sciences and effective teaching in Tertiary institutions.

\section{Problems Hindering Effective Implementation of Integrated Science Programme}

Among the factors affecting Science or integrated science teaching in Nigeria are:

1. Poor planning.

2. Methodology used in teaching (science teaching).

3. Lack of infrastructure, laboratory and facilities. 


\section{Period allocated for Science teaching.}

\section{1) POOR PLANNING}

Planning makes for effectiveness and efficiency of a programme. Many of the science programmed introduced in the early 70s failed and did not see the light of the day due to poor planning and implementation. According to Ukeje(2000) no educational programme can be effectively executed without adequate planning.

\section{2) METHODOLOGY IN SCIENCE TEACHING}

According to Yoloye (1978), Integrated Science as a subject was introduced to improve the quality of science teaching in Nigeria, at the Junior Secondary School. Where it is taught in higher institutions as a course or programme, it is meant to have adequate and well trained teachers who would have acquired necessary skills to handle the subject more effectively.

The way and manner a teacher handles a course/subject goes a long way in promoting or discouraging students from offering sciences (Olorundare, 1998). In the national policy on education, the Federal Government (FRN, 1985) emphasized that teachers of integrated science are expected to use activity-oriented approach such as demonstration, discovery and problem solving. In science generally the focus should be on how to develop in the students ability to apply simple scientific principles in a new situation and acquired scientific attitude in solving problems.

According to Waston (1971) the two main methods that have been proved to be useful in teaching science concept include the act of:

1. Informing the students about some selected facts, principles, laws and concepts so that students only have to listen and memorize where necessary.

2. Providing experiences or appropriate situation that could encourage the students to discover by themselves through observation, manipulation, experimentation and discovery.

Besides that analysis of some of the newly introduced science curricula in Nigeria directly or indirectly advocated for a specific approach to teaching, depending on the subject concerned. In all, each calls for active students' participation through experimentation and discussion as against the use of lecture method or storytelling. Science teachers therefore are encouraged to assist the students to acquire scientific knowledge through purposeful use of all or most of their five senses. In this paper attempt is made to discuss integrated science as a course which embraces many science subject. Integrated science is taught as one of the science subjects at the junior secondary school level and offer as a course in the tertiary institutions in order to have well trained and qualified integrated science teachers.

Generally in the activity based approach to science teaching, lessons are designed in such a way that through their mental processes students discover concepts and principles, make necessary observation, learn to organize and carryout investigations, which in turn aids better retention. Talking about integrated science teaching Bajah (1983) argued that the course was introduced in the school curriculum with the intention that it will help satisfy the aims and aspirations of the child as well as that of the society in which a child lives.

Integrated science is defined as an approach to science teaching in which concepts and principles are presented so as to stress the fundamental unity of scientific thought without necessarily making a distinction between various scientific fields.

In integrated science, each scientific concept is selected and discussed to show the inter-relationship among the three basic science subjects, namely biology, chemistry and physics (Bajah, 1978).

According to Bajah, (1978), the meaning of "integration" in integrated science has to do with the belief that:

Several sciences are characterized by a common methodology and that their contents represent a whole and become meaningful when interrelated (p. 27).

To show that it is one thing to have a good plan and it is another thing to put in to practice the recommended strategies in the classroom, OKeke (1973) revealed that many teachers handling science in schools have discouraged some students from offering science subjects mainly because of their approach to teaching thus not allowing the country to have adequate science teachers across the states in Nigeria.

In fact Mani (1981), in a study carried out at Kano revealed that integrated science has not been taught as intended and that lesson presentations are mostly teachercentered which was not in line with the philosophy of integrated science.

In another study carried out by Odubunmi (1980) it was found that:

(a) Students were not actively involved in the lesson and in most cases, the lecture method was used.

(b) Most institutions sampled did not allocate double period of practical for integrated science on their school time table.

(c) Up till then, there were no enough trained and qualified integrated science teachers.

To show the importance of order of presentation during classroom instruction, some psychologists like Piaget, Pavlov, Skinner and others recommended that school instruction and contents should consider the age range of the learners, their interest, social and educational background. The reason being that whatever is to be taught should not be above the age level of the students to allow for easy understanding, assimilation and acquisition of necessary skills. To sum it up, all the three areas of Bloom's Taxonomy of educational objectives namely

(1) Cognitive

(2) Affective and

(3) Psychomotor should be considered in science teaching.

In other words active involvement of the students in an opened process oriented and practical activities is necessary in the development of creative thinking in learners. The problems in most schools has been that the teachers are not performing to expectation and not implementing schools programmes the way it ought to be.

The above statement is supported by the argument raised by Ogunniyi (1978) that more progress would have been made in implementing integrated science programme if not for the following inhibiting factors:

1. poor teacher's preparation. 
2. lack of teaching experience by many teachers who teach the course.

3. too many activities to be performed within a limited time allocated to the course on the school time table.

4. more emphasis on process to almost a total exclusion of product of science.

Another important factor that is known to be affecting the teaching of sciences in most of the tertiary institutions is the availability of facilities or instructional materials.

\section{3) INSTRUCTIONAL MATERIALS, LABORATORY AND FACILITIES}

Classroom teaching and learning demands a lot of materials for arousing or motivating the interest of the learner for concretizing learning experience, retention and transfer of knowledge. Although there are some improvements or progress made in this area, more are still needed in the area of provision of Textbooks, laboratory manuals, Chemicals and Specimens. According to Nwosu (2002) inadequate supply of learning material leads to student poor performance. Definitely there is bound to be a problem, even if a teacher possesses good mastery of the subject matter but cannot get appropriate and adequate materials, equipment, laboratory hardware's, specimens and chemicals with which he can demonstrate what he/she wanted the students to learn. Among the factors that are commonly spoken of in the literature for mass failure or poor performance in 'science practical's or external examinations include inadequate laboratory equipment, specimens, student size or population in a class and incompetency on the part of some teachers (Ogunniyi, 1978).

In support of the above, Bajah (1983) reported that when the instructional or Laboratory materials and specimens are made readily available and used appropriately, they serve as an effective means of showing the students how the scientists work or how theories are derived. Not only that, ether in Biology, Chemistry, Physics or other science related course when students are widely exposed to practical works they would acquire all the necessary skills and retained them very well all that they were taught.

It is for this reason that science teachers are expected to organize science content and select appropriate methodology in such a way that students practice rather than merely learning science. Practical works among other things provide students with the opportunities of engaging on experimentation, observation and investigation thus improving their scientific skills for the future use.

Some aspects of scientific attitudes and skills that can be developed by the students when fully engaged in student centered or activity based practical activities include: Curiosity, open mindedness, objectivity, honesty and precision.

\section{4) LESSON PERIOD (TIME)}

One of the problems identified in the teaching of sciences particularly Integrated science is time factor. Most teachers often complain that the teaching periods allocated for integrated science on the school time table is three (3) hours instead of the five(5) hours suggested by the curriculum committee. When there is much to be covered particularly at the approach of the final JSC Exam, there is tendency for teachers to adopt lecture instead of the child centered approach.

In conclusion, there is need for science teachers to be conscious of their classroom behaviors, select appropriate methodology depending on the topic to be taught and provide enough time for laboratory work to promote science teaching and learning. The habit of having to borrow laboratory specimens, equipment and chemical most especially when the examination is approaching should be discouraged.

\section{Conclusion and Recommendations}

The decision making procedure in Nigeria society are inadequate for people appear not to be interested in wanting to change from their old ways of doing things. All teacher education programmes should be capable of helping in producing new breeds of teachers, category of teachers who are community conscious, qualified to carry out effective job; energetic; and innovative. That is those who are interested in teaching not because they could not get alternative job.

The importance of the study of sciences in Nigerian tertiary institutions and handling of the science courses the way it ought to be handled cannot be over-emphasized. The progress made so far in the advanced countries like China, Japan, UK and America is as a result of the efforts and emphasis put in to science learning. All the science teachers across the nation should endeavor to promote development of certain skills through the way they handle their teaching.

On the basis of what had been discussed, it is hereby recommended that:

(a) all the apparatus, equipment, chemicals and specimen should be made readily available before the commencement of laboratory work.

(b) students should be made to observe critically and take good care of pets or animals that are kept in the school for practical.

(c) where students had to study wild animals, necessary agreement should be made for the students to go on field trip or excursion to a zoo.

(d) proper dressing in the laboratory and maintenance of laboratory materials following their usage should be encouraged among the students.

(e) effort should be made to promote transfer of knowledge by allowing the students to see the relationship between what is learned in the classroom and the challenges ahead in future.

(f) effort should be made to present topics as spelt out in the subject curriculum or course outline.

(g) teacher should show interest in teaching and teach in such a way that the students are encouraged to acquire the right attitude and skills.

(h) for most topics students should be encouraged to observe, read supplementary materials, record information, investigate and make self-independent study.

(i) all the tertiary institution should make available to the public all teacher education programmes in their institution for easy comparison and to enable people make their choice.

(j) teachers should be required to be more actively involved in the process of change, probably through a lively and more recognized professional associations. 
(k) Journals and publications by publishing houses in higher institutions of learning should be made available such that the lecturers can learn from and update their knowledge toward helping the future teachers perform their jobs more effectively.

Finally, what matter is not only to know what to do but doing it right and using strategy that will bring about the desired learning. For there is urgent need to constantly examine what actually is in operation in the classrooms in terms of instructional strategy, teachers dedication to work and the efforts made in ensuring accessibility of all laboratory materials. This is necessary for the students to be able to observe, experiment, manipulate, interpret and make conclusion, in addition to learning appropriate skills for immediate or future use.

\section{References}

[1] Abdullahi, A.(1987). Science Teaching in Nigeria. Ilorin: Atoto Press.

[2] Bajah, S.T. (1983). Teaching Integrated Science Effectively. Ibadan: University `Press.

[3] Federal Republic of Nigeria (FRN, 1985). National Policy on Education. Revised Edition, Federal Government Press.

[4] Ilugubush, A. A. \& Ogunseni E.O. (2012). Ensuring equal opportunities in Science and Technology Literacy: Focus on
Gender Disparity in Science Classroom. Nigerian Educational Digest, 12 (1), 285-292.

[5] Mani, C. (1981). The gap between the intended and the operational forms of the NISP. Paper presented at the $22^{\text {nd }}$ Annual Conference of STAN.

[6] Obomanu, J.B. \& Akporehwe N.J. (2010). The effective of using manipulative materials and lecture method in Teaching Senior Secondary Schools Biology in Bayelsa State. Trends in Educational Studies Journal, (1\&2), 231-244.

[7] Ogunniyi, M.B. (1978). Determinants of successful implementation of the integrated Science Programming in Nigeria. Journal of the Science Teachers Association of Nigeria, 16 (2), 50-58.

[8] Okeke, A.N. (1973). The impact of Schools on the choice of occupations and 'Professions. West African Journal of Education, 17 (1), 5-15.

[9] Olorundare, S.T. (1988). Scientific literacy in Nigeria. The role of Science Education programmes: International Journal of Science Education, 10 (2), 151-158.

[10] Nwosu, S.E. (2002). Fundametals of Computer education an educational technology enugu. cedartop.

[11] Silva, R. (1982). The rationale frontiers of Science. Florida: Krieger Publishing Company.

[12] Ukeje, B.O. (2000). Universal basic education in Nigeria. Logistic and Implementation initiatives. Lead paper presentation at a workshop on UBE. University of Nigeria, Nsuka, $4^{\text {th }}$ July.

[13] Weston, F (1971). Science Curriculum in Schools. The Encyclopedia of Education, 8, 101-107.

[14] Yoloye, A (1978). Evaluatiion for innovation African Primary Science Programmes. Evaluation Report: Ibadan: University Press. 